\title{
AN ANALYSIS OF THINK-PAIR-SHARE STRATEGY ON GOOGLE CLASSROOM IN READING AT SMKN 1 KUTA SELATAN
}

\author{
K.P.D. Wijaya ${ }^{1}$, N.M. Ratminingsih ${ }^{2}$, I.G. Budasi ${ }^{3}$ \\ ${ }^{123}$ English Language Education, Universitas Pendidikan Ganesha, Singaraja \\ e-mail: pradityadicky131719@gmail.com, made.ratminingsih@undiksha.ac.id, gede.budasi@undiksha.ac.id
}

This study aimed at analysing the implementation of TPS strategy on Google Classroom in reading at SMKN 1 Kuta Selatan. Descriptive qualitative was used as a research design. A purposive sampling technique was applied to choose 3 English teachers and 117 students as the research subjects. An observation sheet, closed-ended questionnaires, and semistructured interview guide were used to collect the data. The results showed that the teachers create many forums on Google Classroom in providing the students with the opportunities to implement TPS strategy, namely; posting a text, providing some questions, asking the students to work in pairs, and collecting the results of their discussion. Teachers' perceptions show that $84.37 \%$ are very good and $15.63 \%$ are good. While students' perceptions show that $8.82 \%$ are very good, $70,6 \%$ are good, and $20,58 \%$ are enough. Increasing students' enthusiasm and motivation to read a text became one of the teachers' reasons for using TPS strategy on Google Classroom.

\section{Keywords: Google Classroom; Reading; Think Pair Share Strategy}

\section{INTRODUCTION}

Education is a series of steps in learning which points to acquire information, hone aptitudes, and develop students' character. Biesta (2015) mentioned that in education, educators have an imperative part within the learning process because they help students to gain knowledge, character, and skill. They transfer and actualize the knowledge to students. Numerous teaching techniques, methods, and strategies are chosen by educators to help students to accelerate their learning. Previous studies found that teachers found problems in selecting appropriate methods and strategies for teaching. Lampert's study (1985) found that teaching methods cannot be applied optimally because the situation in the classroom sometimes is not like what the teachers expected. Moreover, teachers are also confronted with the problem of enhancing students' understanding or completing the educational programs (curriculum).

In accordance to Gocer (2008), a professional teacher is the one who has quality in the selection of strategies and methods to be implemented in the learning process. Besides, in 21 st century learning as it is today, education focuses on student-centered approaches. Killen (1996) stated that student-centered is discovery, inductive, or inquiry learning in which students become more active in the learning process and the teachers only play a role as a facilitator. It requires the teachers to be able to adjust the selection of learning strategies or methods to be used. They need a strategy or method to make the learning process becomes effective. In reference to this, Cooperative Learning (henceforth $\mathrm{CL}$ ) is one of the learning models that is popular and widely used in the learning process. Killen (1996) defined CL as a learning model that encourage students to learn in groups and be able to interact either between friends in groups or between groups. Johnson \& Johnson (1975) as cited in Thanh (2008:4) mentioned there are five elements in the CL activities, namely positive interdependence, individual accountability, face-to-face promotive interaction, interpersonal and small group skills, and group processing. CL consists of several strategies that can be chosen according to learning needs, one of which is Think-Pair-Share (TPS).

As reported by Richards \& Rodgers (2001), TPS strategy is implemented with reference to several stages, the first is the process in which the teacher provides a topic or question to the student; then, the student are given a time to think, then they discuss with their partners in the groups, and afterwards they share the results of their thoughts and 
discussion related to the topics that have been given by the teacher. Kagan (2009) as cited in Sugiarto \& Sumarsono (2014) mentioned TPS strategy consist of five steps: First, organizing students into pairs (i.e. the teacher divides and asks the students to work in pairs; second, Posting a topic or a question

(i.e. The teacher gives some general questions to the students and it is expected that they are able to answer those questions by using their prior knowledge); third, Giving time to students to think (i.e. The teacher gives time to students to use their critical thinking to answer the question), fourth, Asking students to discuss with their partner and share their thought (i.e. The students start work in pairs to discuss their idea, opinion, and answer. They are expected to be able to develop their potential to analyze the different thoughts or opinions. It also improves their communicative skills due to the interactions that occur in the discussion); and fifth, Calling on a few students to share their ideas with the rest of the class (i.e. In the last stage, the students present and share the result of their discussion with the whole class while the other students listen and give comments).

Several studies prove that TPS strategy can be implemented in language teaching, one of which is to teach reading. Reading is one of the language skills that needs to be highlighted because based on Program for International Student Assessment (PISA), reading interest in Indonesia is still in the lower level. According to OECD, 2014b as cited in Suprapto (2016), the rank of PISA in 2012 in Indonesia was in the $64^{\text {th }}$ position. The mean score of reading in Indonesia is 396 with the standard 492. In 2015, the mean score of reading in Indonesia is 397 with the standard 493 and in 2018 the mean score of reading in Indonesia is 371 with the standard 487.

The main problem of students in reading is they lack of vocabulary and find it hard to understand the content of the text. According to Bndaka (2007), some students in Greece have difficulty and feel uncomfortable when they read the text in which the language is real or language that has never been read. Meanwhile, students in Indonesia are more motivated in reading on external than intrinsic factors (Indrayadi, 2021). The external factor is the students want to obtain good grades on reading and obtain appreciation from teachers, friends, and others. Bouffard-Bouchard et al. (1991) stated that students will be motivated to learn when students know the way how to learn better.

The demand of the teachers in the Covid-19 pandemic is to require that the learning process of reading be carried out through online learning. According to Istifci (2016), online learning is needed by the students to obtain feedback on independent learning from the teachers. However, the reality is that teachers have not been able to use technology optimally. Sipilä (2013) states that the majority of teachers do not know to use ICT. It makes them unprepared to use it in the teaching and learning process. Spiteri \& Chang Rundgren (2020) revealed that the teachers require skills and knowledge in using ICT. Therefore, they should practice well. One of the technologies as online learning platform is Google Classroom. Iftakhar Shampa (2016) stated that implementing Google Classroom is easy to use or access it. It also helps increase students' willingness to learn and encourage them to become an active learner. Besides, Bhat et al. (2018) explain that Google Classroom is effective as a media to submit the students' assignment rather manual submission.

Based on preliminary observation and informal interviews with one of the teachers, the researcher obtained that the teachers at SMKN 1 Kuta Selatan have implemented TPS strategy to improve reading comprehension on Google Classroom. They have implemented the TPS strategy when teaching and learning reading activities are still conducted face-toface. However, due to the Covid-19 pandemic, they have to implement the TPS strategy through Google Classroom. Nevertheless, no one has evaluated the implementation of TPS strategy in reading comprehension on the Google Classroom. Besides, Tuanany (2019) states that implementing TPS strategy makes teachers unable to prepare the lesson plans accurately. In addition, many students are noisy when they have discussions. While Sampsel (2013) reveals that students focus on the learning material when the teacher implements the TPS strategy. Therefore, the researcher is encouraged to conduct a study that focuses on analyzing the implementation of the TPS strategy in reading on the Google Classroom at SMKN 1 Kuta Selatan, and describe the teachers' and students' perceptions about reading through the platform. 


\section{RESEARCH METHOD}

This study was in the form of qualitative research. In conducting the analysis, this study used the latest interactive model of qualitative data analysis proposed by Miles, Huberman, \& Saldana. It consists of four streams namely, data collection, data reduction, data display, and conclusion drawing.

The researcher gathered the data through observation, in which the researcher observed, took notes and photos of all the activities between teachers and students on Google Classroom. This was done after the researcher got access permission from the teachers. Observation was carried out according to the observation sheet that has been validated by expert judgments. The observation was conducted for approximately 1 month. In term of collecting the data regarding teachers' and students' perceptions of using TPS strategy, the researcher used closed-ended questionnaires which consisted of 32 items for teachers' perceptions and 34 items for students' perceptions that covered positive and negative statements. After observing teaching activities and distributing questionnaire, the researcher conducted semi-structured interview with the three subjects in order to collect additional data about the reasons behind the implementation of TPS strategy on Google Classroom.

Then, it comes up with data reduction in which the researcher focused on the data needed. In this step, the researcher transcribed the recording of interviews into written form between the researcher and the teachers as the subject of this study. Afterwards, the data were selected and classified in accordance with the research purpose. After the data were reduced, the researcher displayed the data in the form of tables and pictures. The tables were in the form of percentage tables which consist of percentage table regarding teachers' and students' perceptions of TPS strategy and Google Classroom. While, the pictures were screenshots of the TPS strategy implementation on Google Classroom. Thereafter, the data were elaborated in the form of paragraph explanation which is supported by theories of TPS strategy and UTAUT2. The process of this analysis was done simultaneously, which enable the researcher to go back and forth before drawing the final conclusion.

\section{FINDINGS AND DISCUSSION}

The results of this study were obtained through three stages namely, observing the learning process using TPS strategy in reading comprehension on the Google Classroom, distributing the questionnaires to students and teachers, and conducting interviews with teachers to gain additional information. The researcher conducted observation by requesting access to Google Classroom as a Co-teacher in order to see the activities between teachers and students in Google Classroom. The results of the observation are shown as follows.

\section{a. Think Stage}

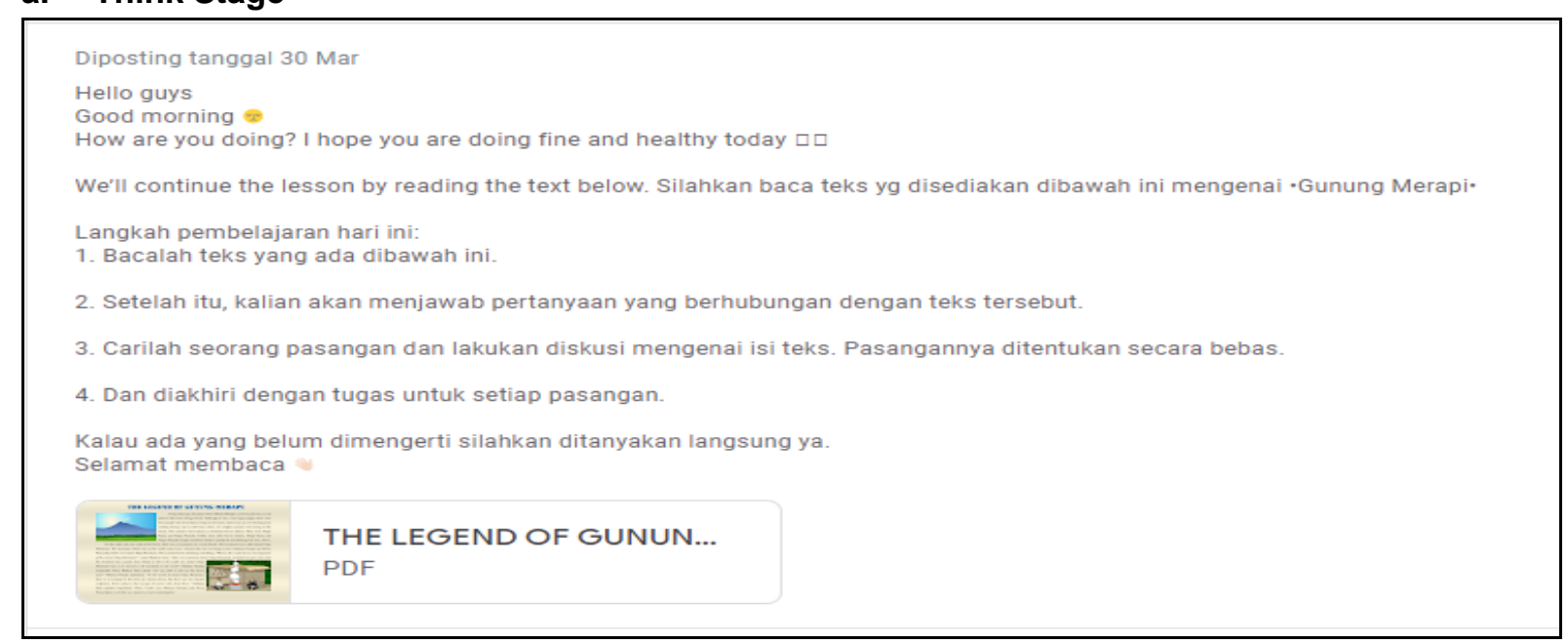

Picture 1. Subject I Provided A Text To Students 
Holla,

Kita sampai di langkah kedua pembelajaran hari ini. Berikut adalah tugas yang dikerjakan

Picture 2. Subject I Provided Several Questions To Students

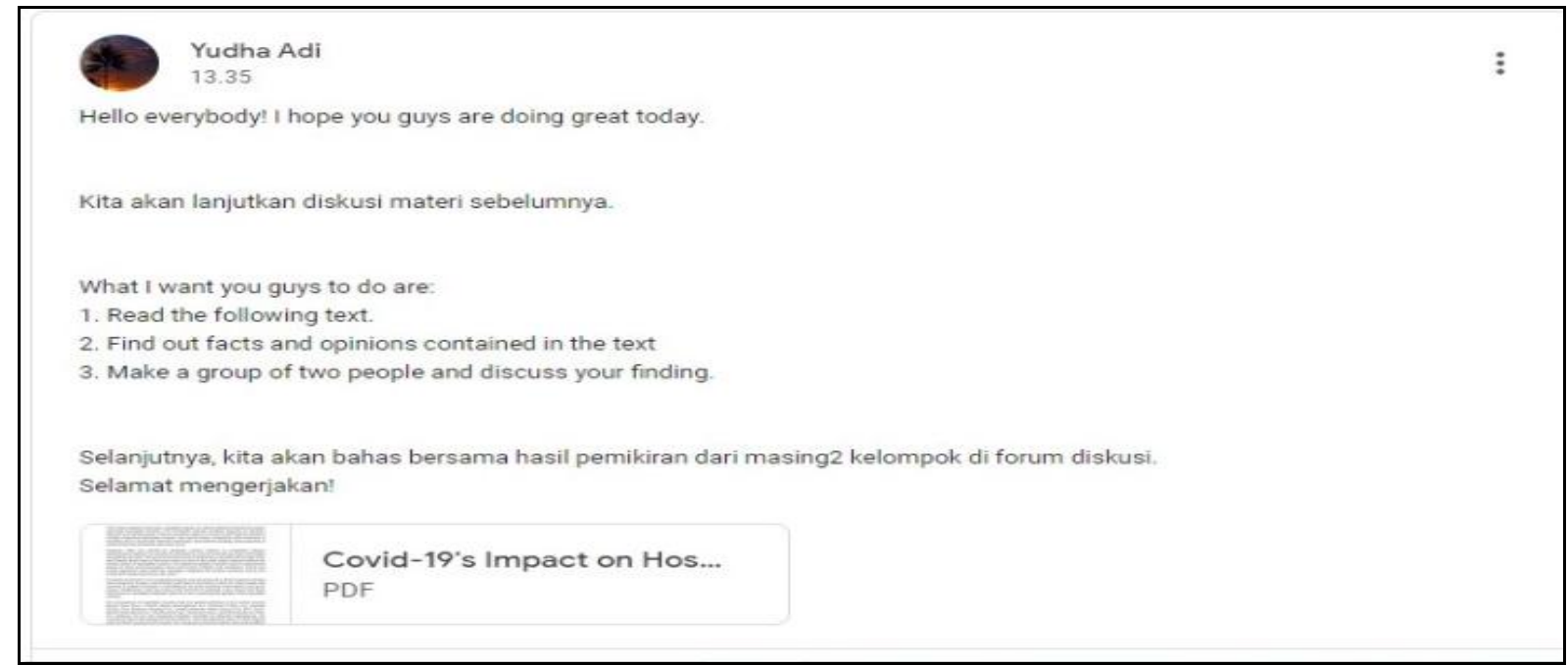

Picture 3. Subject II Provided A Text To Students

\section{Ketut Muliana}

09.50

Hello. This week we will learn about analytical exposition text.

As an outset, saya ingin kalian membaca teks yg sudah saya attach di bawah ini.

Then, please think about what is the writer's intention of writing the text!?

\section{The Dangerous Effects of ... Google Dokumen}

\section{Picture 4. Subject III Provided A Text To Students}

Based on the pictures above, it can be seen that each teacher carried out the stage of thinking with several steps, namely; providing a text, asking students to read the text, and providing several questions related to the text. The significant difference can be seen in the way teachers provided questions on Google Classroom. In picture 1, Subject I provided a reading text on a forum of Google Classroom. Then, in picture 2, subject I created a new forum to provide several questions related to the text via Google Form. Meanwhile, in pictures 3 and 4 , subjects II and III only created one forum to provide a text along with the instructions and questions. 


\section{b. Pair Stage}

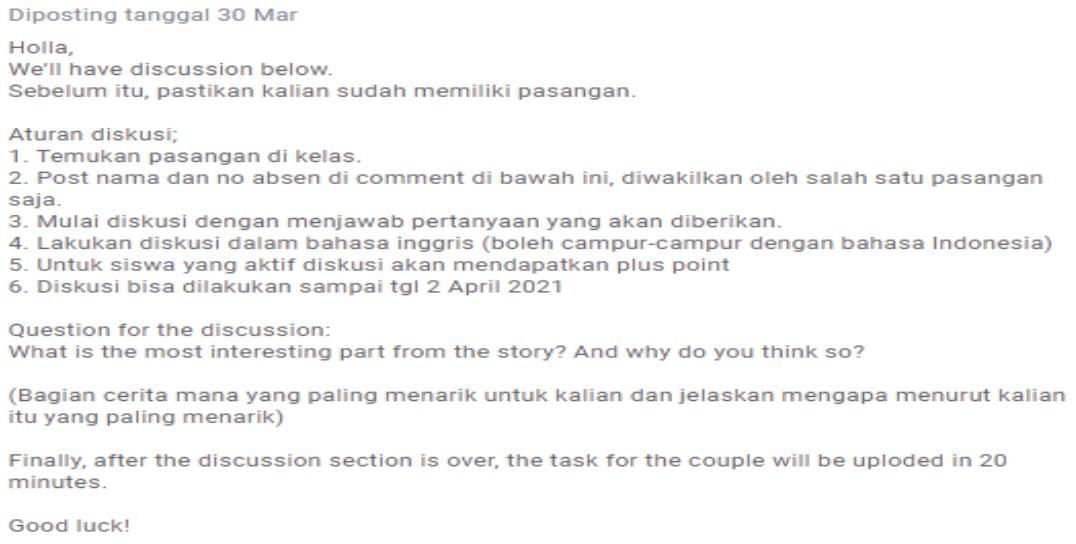

Picture 5. Subject I Provided The Instruction About The Discussion

Revian Iqbal Fanani 10.55

- Revian Iqbal Fanani 25

- Kadek Surya Amerta 20

5 balasan

Dek Surya16 11.07

in the battle between Batara Narada, the deva of drawing against the master of rama and the master of pamadi, because the master rama and the master pamadi do not want the quality of his keris to decline

Revian lqbal Fanani 12.32

This story is interesting because this mountain is one of the active mountains in Indonesia and the story is also interesting. There are two masters who have the power to fight Batara Narada and Dewa Penyarik so that the quality of the keris does not decrease and is related to the incident during the war between Empu Rama against Batara Narada and the God of Puller against Empu Pamadi, the pulling god and the master rama decided to fly the mountain silently to the spot. Empu Rama and Empu Pamadi

Revian Iqbal Fanani 12.32

jawabannya dipake yang dibawah nggih pak

I Dewa Gde Agung Ananta Kusuma 13.18

Well done Dek Surya and Revian

Activate Windows

Picture 6. The Situation Of Discussion In The Class Of Subject I

Hai everyone. Here's the room for you guys to conduct the discussion.

Jadi silakan kalian diskusikan apa yang saya instruksikan sebelumnya di kolom komentar dibawah ini!

Mention nama lengkap kalian dan pasangan, dan juga attendee's number!

1 give you 3 days to have a discussion.

Good luck!

83. 4 komentar kelas

Cindy Aurellya 12.30

Good afternoon Mr. Yudha

Name: Ni Putu Cindy Aurellya (05) and Bellyna Putri Annisa (02)

- It includes the decrease in tours and travels as most of the flights

are getting canceled. Menurut saya dan bellyna, kalimat ini termasuk fakta karena merupakan keadaan yg nyata terjadi

- The hospitality industry certainly depends on people's desire to visit certain places. Menurut kami, kalimat ini adalah opini penulis

Terimakasih. Maaf jika salah $\mathrm{mr}$.

Picture 7. The Instruction And Discussion Conducted In The Class Of Subject II 


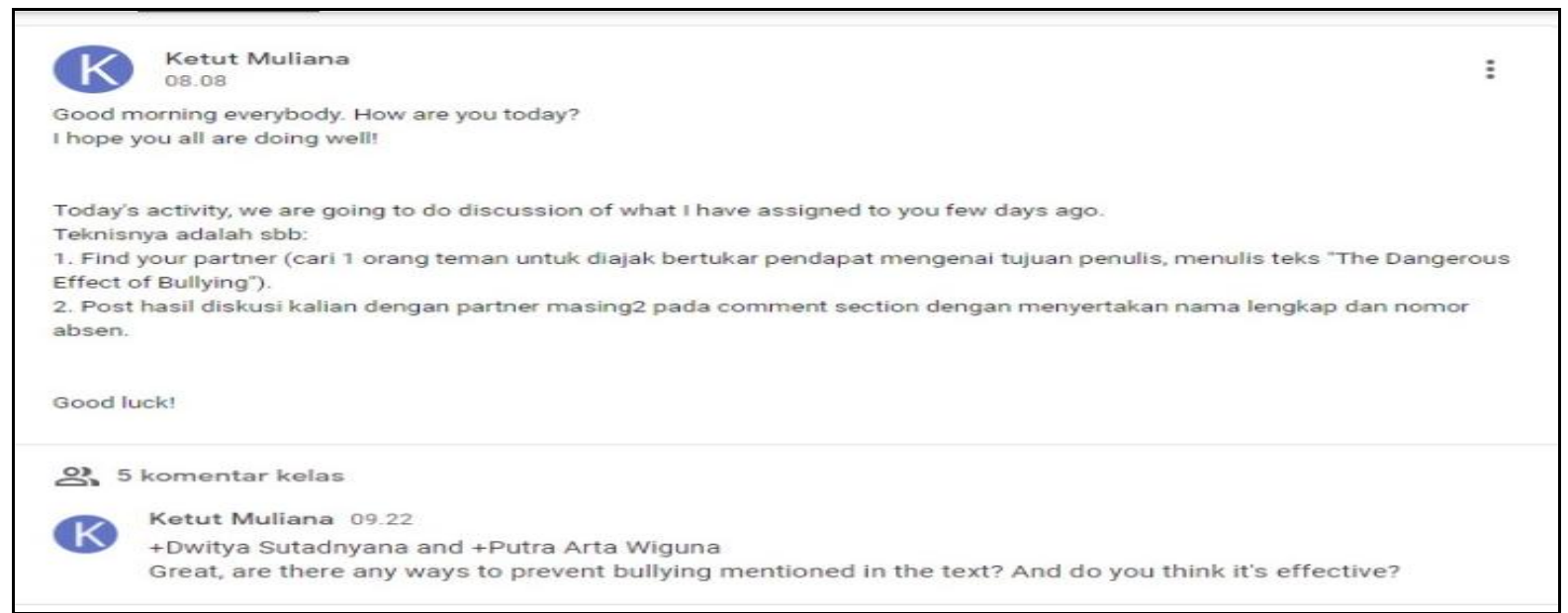

Picture 8. The Instruction That Was Given By Subject III

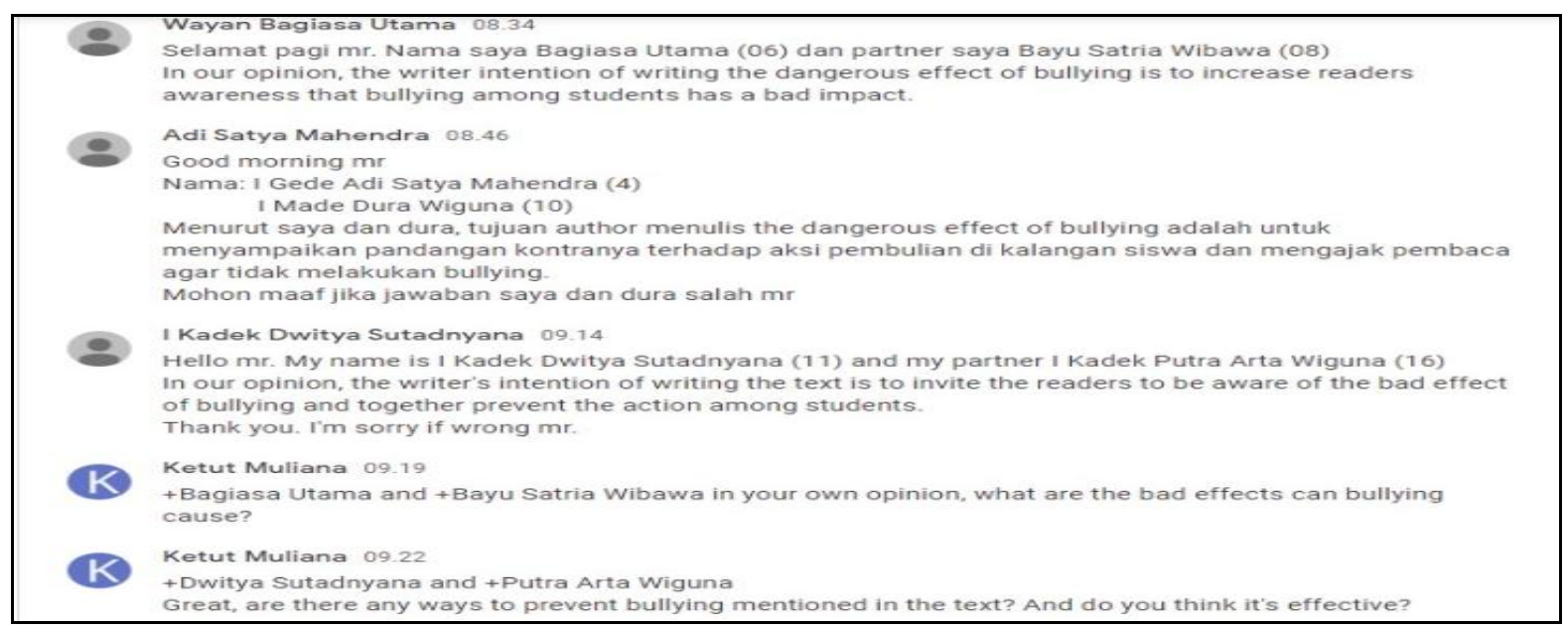

\section{Picture 9. The Situation Of Discussion In The Class Of Subject III}

Based on the pictures above, the pair stage was well conducted by the students. The teachers provided clear instructions before starting the pair stage which is a discussion session. It was carried out to avoid students' confusion in conducting discussions. The teachers conducted the discussions on Google Classroom in different ways. In picture 5, it can be seen that subject I created a specific discussion forum containing instructions for carrying out the discussion. Furthermore, in picture 6 , students must go into the specific forum to participate in discussion activities. In contrast to the way that was done by subject II (in picture 7) and subject 3 (in pictures 8 and 9), they only created a normal forum so that the discussions can be carried out in that forum.

\section{c. Share Stage}

Diposting tanggal 30 Mar

Here's the task for you!

Make a list of events that you consider to be interesing (bagian cerita yang menarik bisa saja menarik seru, lucu, aneh dan sebagainya). At least, 5 events in the story.

Sesuai dengan yang telah didiskusilan dengan pasangan kalian di bagian sebelumnya.

For example:

Interesting Events

1. When Empu Rama and Empu P smoldered the Keris bare handed without any tools. 2 .

3.

4.

Picture 10. Subject I Asked The Students To Share The Result Of Their Discussion Jurnal Pendidikan Bahasa Inggris Indonesia | 95 


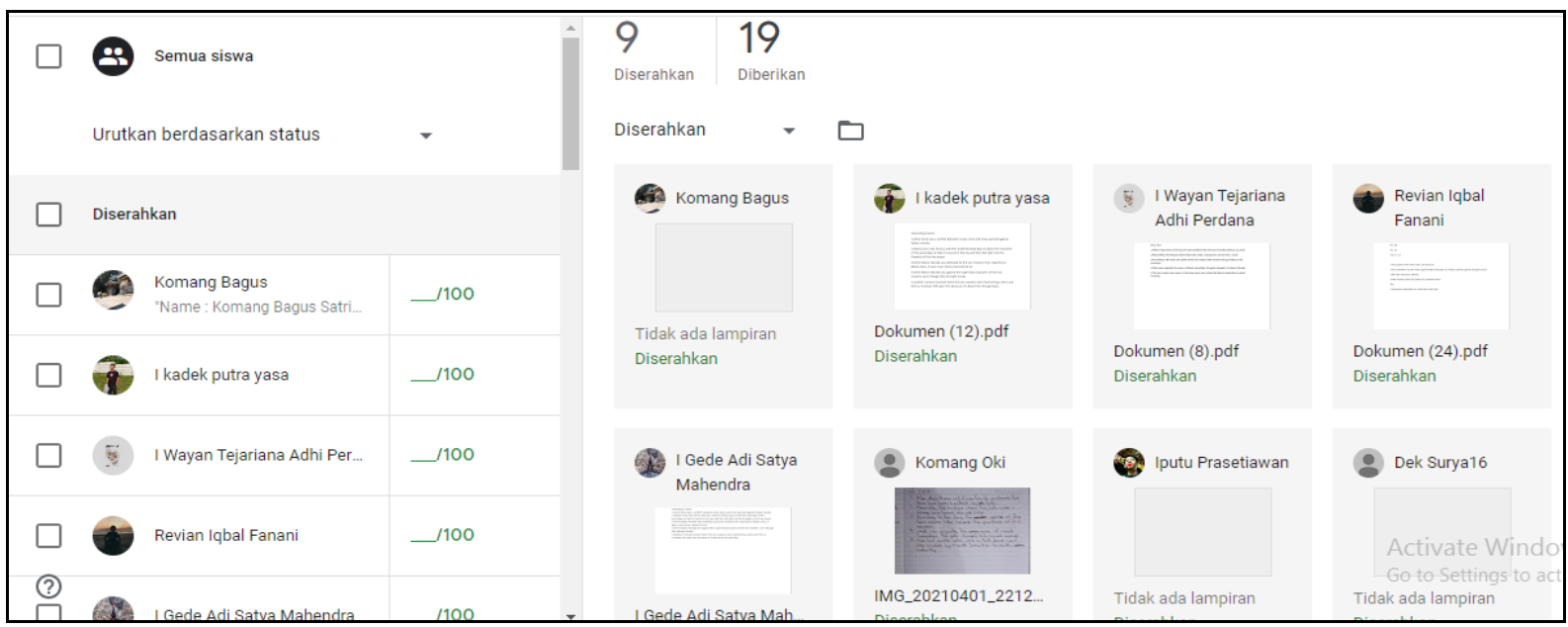

Picture 11. The Students Of Subject I Sent The Result Of Their Discussion

What's up, everyone! It's time for you guys to share the result of your discussion.

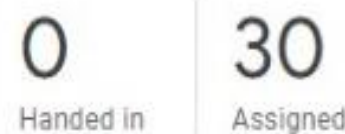

Silakan list fakta dan opini yang kalian temukan dalam teks "The Impact of Covid-19 on Hospitality".

Buat dalam bentuk file word dengan mencantumkan nama lengkap + nomor absen kalian dan partner.

Yang upload perwakilan saja ya.

Thank vou.

Picture 12. The Instruction Of Subject II To Share The Result Of Students' Discussion

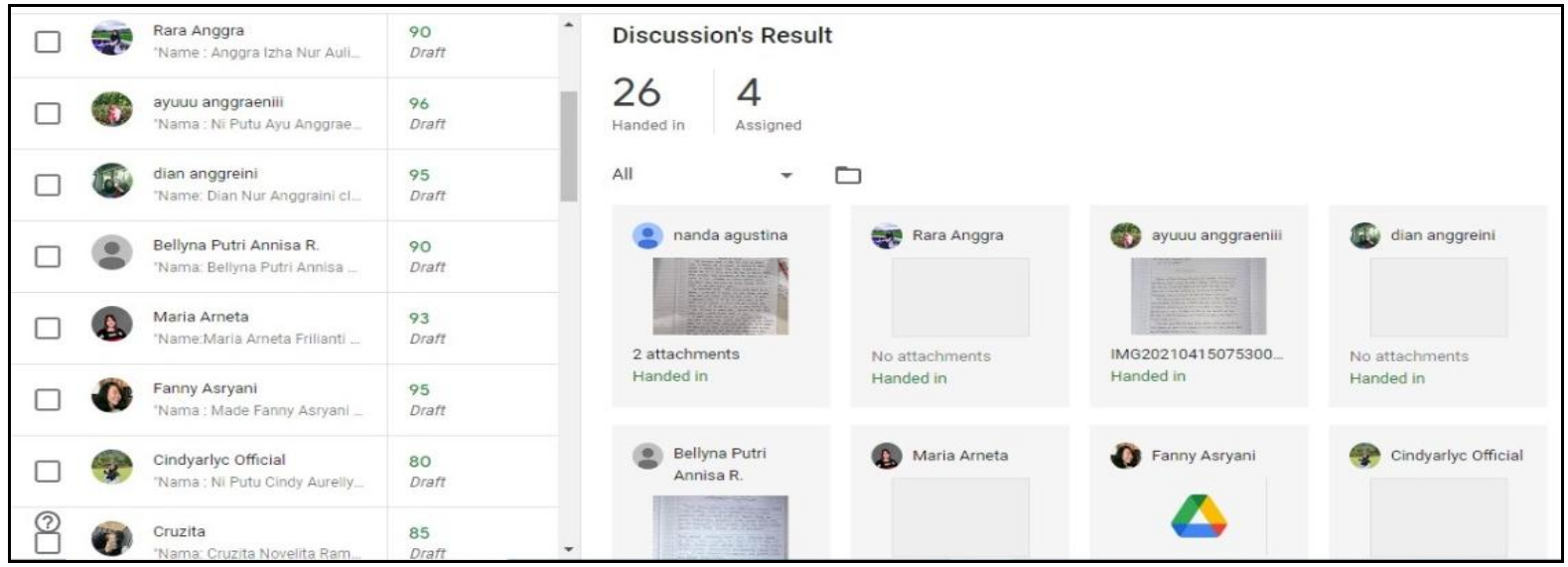

Picture 13. The students of subject II sent the result of thier discussion 


\section{No due date}

After reading the text and examining the writer's intention of writing the dangerous effect of bullying, now it's your turn to give your opinion about bullying from your point of view as a student. Write in a short paragraph (maximum of 2 paragraphs) and submit
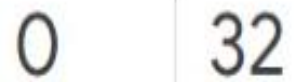

Handed in Assigned

it in the provided section!

Deadline until next week, so make sure you all submit it.

Have a good time doing it!

Picture 14. The instruction of subject III to share the result of students' discussion

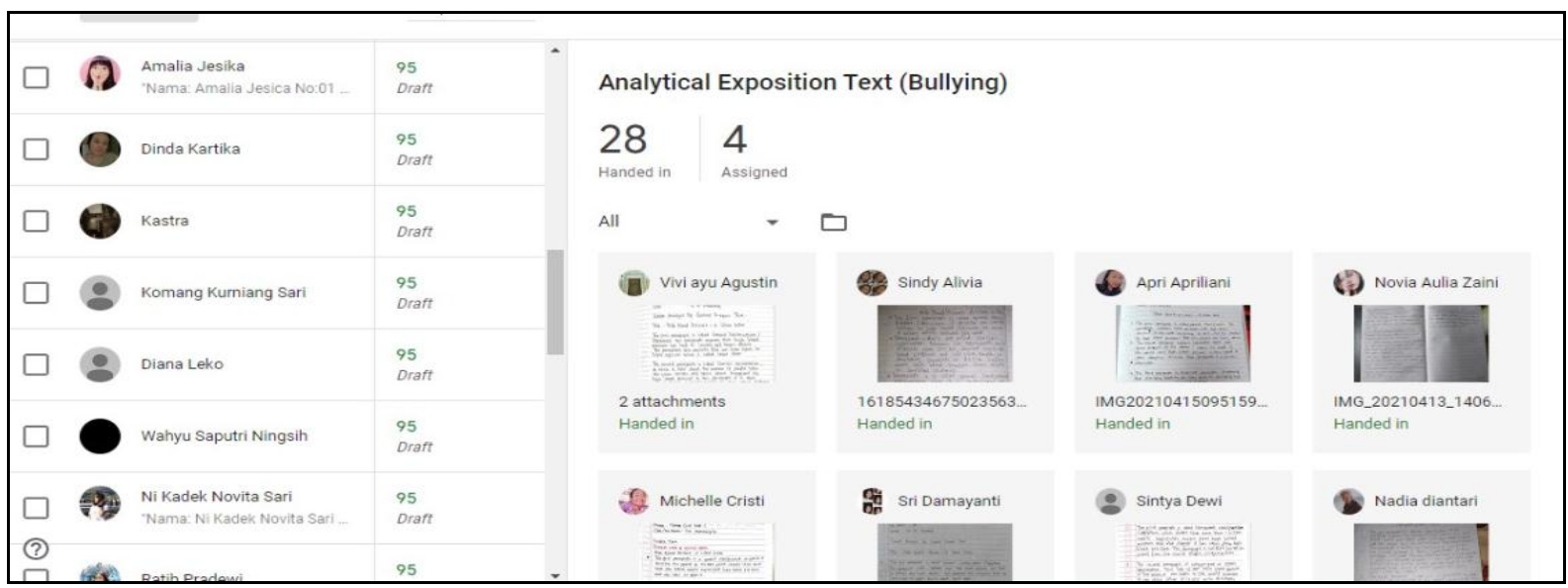

Picture 15. The students of subject III sent the result of thier discussion

The pictures above show that the teachers asked students to collect the results of their discussions individually. It can be seen from the picture 10,12, and 14 that the subjects provided instructions to students to collect the assignments that were given. Furthermore, the subjects created a forum for assignment submission on Google Classroom which used by students to submit their assignment. However, from the results of the researcher's observations, some students were inactive in collecting assignments on Google Classroom.

The data analysis found that each teacher had different way in creating several forums to implement the TPS strategy. Firstly, the teachers provided a forum containing a text that should be read by students. Secondly, the teachers provided some questions via Google Form. Then, the teachers instructed the students to discuss the given questions. In the last forum using TPS, the teachers asked the students to collect the results of their discussion. Many students experienced confusion in taking a reading class using the TPS strategy on Google Classroom. It is because they usually discuss face-to-face, then suddenly it turns into a discussion through Google Classroom. As a result, some students were inactive in the discussion session.

Teachers' Perception of Using TPS Strategy on Google Classroom

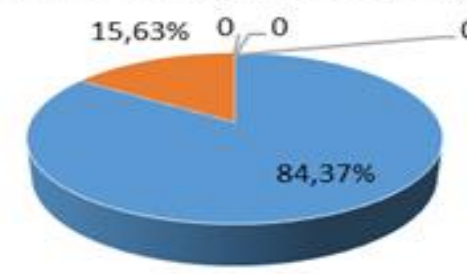

= Very Good " Good " Enough " Bad " Poor

Chart 1. The Percentage Of Teachers' Perceptions 
Chart 1 indicates that $84.37 \%$ of teachers' perceptions of using TPS strategy on Google Classroom are categorized as very good criteria. Furthermore, as many as $15.63 \%$ of teachers' perceptions are categorized as good criteria. On the other hand, $0 \%$ shows that there are no criteria of enough, bad, and poor in the teachers' perception. Thus, 32 items of the questionnaire related to the teachers' perceptions of using TPS strategy on Google Classroom have a very good result. The teachers never continue the next learning activity without giving thinking time to the students to understand the text. According to Raba (2017), giving students time to think will allow them to discover what they want and need to know. Besides, they always invite their students to discuss and collaborate with their partners. As Raba (2017) and Sugiarto \& Sumarsono (2014) conveyed, through discussion students can listen and respect each other's ideas and thoughts. Then, two of the research subjects had the perception that they always invite students to convey the results of their discussions. However, another teacher had the perception that delivering a discussion will waste learning time. TPS strategy has implemented on Google Classroom by the teachers. They were able to use and operate Google Classroom properly. These features were not complicated and easy to understand. In line with the results found by Al-Maroof \& Al- Emran (2018), Shaharanee et al. (2016), and Heggart \& Yoo (2018), Google Classroom is an online learning platform that is very easy to operate, free to use, and easy to access the material in the form of PowerPoint (PPT), portable document format (PDF), videos on YouTube. Due to the learning process carried out through an online learning platform, teachers' perceptions showed that they were getting used to operating Google Classroom to implement TPS strategy. Thus, they have high motivation and interest to teach reading using TPS strategy on Google Classroom.

\section{Students' Perceptions of Using TPS Strategy on Google Classroom}

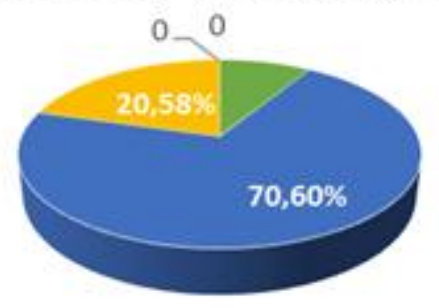

- Very Good = Good = Enough " Bad = Poor

\section{Chart 2. The percentage of students' perceptions}

Chart 2 describes that $8.82 \%$ of students' perceptions of using TPS strategy on Google Classroom are categorized as very good criteria, and as many as $70.6 \%$ of students' perceptions are categorized as good criteria. Then, $20.58 \%$ indicate that students' perceptions are categorized as enough. On the other hand, $0 \%$ shows that there are no criteria of bad and poor in the students' perceptions. Thus, 34 items of the questionnaire related to the students' perceptions of using TPS strategy on Google Classroom have a good result. The students always obtained thinking time about the text. Thinking time can help them to discover new ideas. Furthermore, Raba (2017) revealed that if the students use their thinking time properly, they will be able to avoid misunderstandings in reading the text. Besides, they were able to discuss with their partner, able to listen and accept their partner's opinions, and able to solve problems. The students can understand the results of their discussions and can re-explain what they have discussed with their partners. Based on research from Yulianingsih (2017), TPS strategy provides advantages for students such as increasing their interest and enthusiasm in reading descriptive text. The reasons why teachers implemented the TPS strategy on Google classroom were they wanted to increase enthusiasm and motivation of students to read a text. Teachers preferred to use the TPS strategy because the strategy helps students to use their thinking skills. This is supported by Shih \& Reynolds (2015), Ageasta \& Oktavia (2018), and Yulianingsih (2017) who revealed that TPS strategy is an alternative strategy to increase student motivation in reading. The 
teachers believe that the TPS strategy will help the students who have low abilities. They can exchange their opinions or ideas and help each other to understand the content of the text. It can also be seen in the results of research from Sumekto (2018) that shows the TPS strategy can balance the students' academic diversity. Thus, the teachers did not want the implementation of learning through Google Classroom to be non-optimal. It means that they do not want to just post a text which is followed by a few questions

\section{CONCLUSION AND SUGGESTIONS}

In conclusion, TPS strategy was well implemented on Google Classroom in teaching reading at SMKN 1 Kuta Selatan. In implementing this strategy, the teachers employed several steps, namely posting a text that should be read by the students, providing some questions related to the text, asking the students to work in pairs to discuss the questions given, and collecting the results of their discussion. Teachers' perception regarding the implementation of TPS strategy on Google Classroom can be categorized into two criteria, which are very good with an overall percentage of $84.37 \%$, and good with a percentage of $15.63 \%$. The teachers were able to monitor the discussion activities carried out by students in which it made the learning process became more effective.

In line with this, students' perception of the implementation of TPS strategy on Google Classroom was also getting various responses. Their responses were classified into three criteria, namely very good with a percentage of $8.82 \%$, good as much as $70.6 \%$, and enough as much as $20.58 \%$. The students were able to understand the contents of the text used in the learning activities and provide a chance for students to be able to discuss some questions or new vocabulary. The implementation of TPS strategy on Google Classroom during the Covid-19 pandemic was considered to be able to make the reading class more attractive rather than post a text and ask to answer some questions. Hence, TPS strategy on Google Classroom can be categorized as efficient and practical because it increases the students' motivation in reading.

Based on the result of this research, there are several suggestions are recommended as follows. For students, they should improve their understanding of the use of technology in learning. In a pandemic situation, learning is quite dependent on the use of technology so that students must be more technology literate, so that they can still learn and gain knowledge optimally. In addition, the students could take the advantage of the application of TPS strategy to be more active in reading class. In this strategy, the students getting time to think, discuss with their partners, exchange their ideas and opinions, and convey the context of the text. They can make use of the application of this strategy to practice their skills in expressing opinions.

For teachers, by applying TPS strategy will help increase students' motivation in reading. To implement this strategy on Google Classroom, teachers must manage learning time and have good preparation. In addition, using online learning platform such as Google Classroom requires teachers to know the situation of both students and teachers regarding proper devices and internet connections.

For other researchers, this research can be used as a reference for further research. In addition, many strategies can increase students' motivation in reading and can also be applied in Google Classroom.

\section{REFERENCES}

Al-husain, D., Hammo, B. H., \& Arabia, S. (2015). eT, 4(1), 48-55.

Barton, D. C. (2020). Impacts of the COVID-19 pandemic on field instruction and remote teaching alternatives: Results from a survey of instructors. Ecology and Evolution, 10(22), 12499-12507. https://doi.org/10.1002/ece3.6628

Bogart, W. Van De, \& Wichadee, S. (2015). Exploring Students 'Intention to Use LINE for Academic Purposes Based on Technology Acceptance Model, 16(3), 65-85.

Calabrich, S. L. (2016). Learners 'Perceptions of the Use of Mobile Technology in a TaskBased Language Teaching Experience, 9(12), 120-136. 


\section{http://doi.org/10.5539/ies.v9n12p120}

Creswell. (2012). Educational Research Planning, Conducting and Evaluating Quantitative and Qualitative Research. United States of America: PEARSON

Dashtestani, R. (2013). language learning ( MALL ) in an EFL context : Iranian EFL teachers ' perspectives on challenges and a ff ordances, 9(2), 149-168.

Ferri, F., Grifoni, P., \& Guzzo, T. (2020). Online Learning and Emergency Remote Teaching: Opportunities and Challenges in Emergency Situations. Societies, 10(4), 86. https://doi.org/10.3390/soc10040086

Guzacheva, N. O. (2020). ZOOM TECHNOLOGY AS AN EFFECTIVE TOOL FOR DISTANCE LEARNING. 457-460.

Iskandar, R. \& S. (2019). PEMBELAJARAN KETERAMPILAN BERBAHASA DENGAN MEDIA AUDIO VISUAL MELALUI ZOOM CLOUD MEETING DI FAKULTAS TARBIYAH IAI QAMARUL HUDA BAGU. Journal of Chemical Information and Modeling, 53(9), 1689-1699.

Kaur, C., Singh, S , U., Idris, S., Singh, T., Singh, M., ... Idris, S. (2020). Rethinking English Language Teaching Through Telegram, WhatsApp, Google.11(11),45-54

Marchewka, J. T., \&Kostiwa, K. (2007). An Application of the UTAUT Model for Understanding Student Perceptions Using Course Management Software, 7(2), 93104.

Nugroho, K. A., Kristiyanto, A., \& Doewes, M. (2018). Implementasi pendidikan jasmani dalam international primary curriculum. Jurnal Keolahragaan, 6(2), 110-119. https://doi.org/10.21831/jk.v0i0.21336

Rahayu, D. (2020). Synchronous Zoom Web Conference System: An Exploratory Study on Students' E-Learning Experience. Journal of ELT Research, 5(1), 68-79. https://doi.org/10.22236/JER

Reimers, F., Schleicher, A., Saavedra, J., \& Tuominen, S. (2020). Supporting the continuation of teaching and learning during the COVID-19 pandemic. Oecd, 1-38.

Reynolds, J. A., Cai, V., Choi, J., Faller, S., Hu, M., Kozhumam, A., ... Vohra, A. (2020). Teaching during a pandemic: Using high-impact writing assignments to balance rigor, engagement, flexibility, and workload. Ecology and Evolution, 10(22), 12573-12580. https://doi.org/10.1002/ece3.6776

Sugianto, A. (2020). Applying a Lesson Plan for a Digital Classroom: Challenges and Benefits. 02(02), 21-33.

Sulfasyah, Bahri, A., \& Saleh, S. F. (2018). Writing lessons in grade 1 Indonesian thematic textbooks: A content analysis. Indonesian Journal of Applied Linguistics, 7(3), 495-503. https://doi.org/10.17509/ijal.v7i3.9789

Yinling, C. (2016). Teaching writing. Teaching Language Skills, (August 2016), 113-134. https://doi.org/10.1007/978-3-319-38834-2 